\title{
BLENDING IN WHILE STANDING OUT: SELECTIVE CONFORMITY AND NEW PRODUCT INTRODUCTION IN FAMILY FIRMS
}

\author{
Ambra Mazzelli \\ John Molson School of Business \\ Concordia University \\ Montreal, Quebec (CAN), H3H 0A1 \\ ambra.mazzelli@concordia.ca \\ Josip Kotlar \\ Lancaster University Management School \\ Lancaster (UK), LA1 4YX \\ j.kotlar@lancaster.ac.uk \\ Alfredo De Massis \\ (corresponding author) \\ Free University of Bozen-Bolzano \& Lancaster University \\ Bolzano (IT), 39100 \\ alfredo.demassis@unibz.it
}

Paper accepted for publication in Entrepreneurship Theory \& Practice

An earlier version of this manuscript was presented at the 14th Theories of the Family Enterprise Conference, University of Alberta, Edmonton, Canada, May 25-26 2016. We are indebted to the participants for their helpful comments on the article. We also gratefully acknowledge Isabelle Le Breton-Miller and two anonymous reviewers for their thoughtful guidance and feedback during the review process. 


\title{
Blending In While Standing Out: Selective Conformity and New Product Introduction in Family Firms
}

\begin{abstract}
Research on the conformity-distinctiveness tradeoff in family firms is divided. Examining the product innovations of Spanish manufacturing firms between 1998 and 2012, we hypothesize that family and nonfamily firms conform selectively and are driven by different motivations. Family firms align with their closest peers to avoid social losses while nonfamily firms conform to firms with different attributes to pursue social gains. Moreover, propensity to conform leads to more substantive organizational responses in family firms. We contribute to understanding how family firms navigate the conformity-distinctiveness trade-off, unveil the cognitive dimension of conformity and address the puzzling evidence on family firm innovation.
\end{abstract}

\section{INTRODUCTION}

Every organization faces the confluence of two competing pressures: to look like peers to ensure social acceptance and legitimacy, and to differentiate to gain social recognition (Deephouse, 1999; Zhao, Fisher, Lounsbury, \& Miller, 2016; Zuckerman, 2016). This tension is particularly strong when multiple stakeholder groups with different goals coexist (Berrone et al., 2010). For example, family firms behave in a way that favors family-centered noneconomic goals over purely financial goals (e.g., Chrisman \& Patel, 2012; Patel \& Chrisman, 2014). While their distinctive behavior can help family firms differentiate themselves from their peers (e.g., Miller \& Le Breton-Miller, 2005), external audiences may perceive them as "unorthodox" (Miller, Le Breton-Miller, \& Lester, 2013), risk-averse (Schulze, Lubatkin, Dino, \& Buchholtz, 2001) and less innovative than nonfamily firms (Bertrand \& Schoar, 2006). As a result, external audiences may put family firms through extra scrutiny to discern their nonconformity (Bertrand \& Schoar, 2006), thus increasing the risk of being discounted as illegitimate or penalized (Miller et al., 2013). Although this literature points to a heightened tension between conformity and distinctiveness in family firm innovation behavior, research provides little insight on how family firms navigate this tension. 
The conformity-distinctiveness debate in family business research has built on two theoretical perspectives, namely, the behavioral agency model (Wiseman \& Gomez-Mejia, 1998) and institutional theory (Fiss \& Zajac, 2004), with different assumptions on the role of agency and predictions on family firm behavior. Scholars using the behavioral agency model emphasize internal factors, such as family control and noneconomic goals, as a main driver of distinctive strategic behaviors in family firms (Chrisman \& Patel, 2012; Gomez-Mejia et al., 2007). Institutional theorists conceive agency as externally constrained by regulatory pressures, suggesting that as family firm choices and behaviors are particularly exposed to social assessments, they are more likely to conform and follow the majority to fulfil the expectations of external audiences (Bertrand \& Schoar, 2006; DiMaggio \& Powell, 1983; Miller et al., 2013). Unfortunately, these two research streams have developed separately, with few attempts to integrate their findings. Scholars have commonly approached the distinctiveness-conformity tension in family firms by taking a population-level perspective of conformity focused on homogeneity across firms in a given industry and examining visible yet broad strategic decisions (e.g., Miller \& Chen, 1996; Miller et al., 2013). By treating conformity and distinctiveness as two ends of a continuum (Deephouse, 1999), prior studies have overlooked the possibility that family and nonfamily firms follow different rationales to conform to the behavior of other firms.

Following recent attempts to graft a more agent-based and cognitive model of firm responses to external pressures (e.g., Negro, Hannan, \& Fassiotto, 2015; Sharkey \& Bromley, 2015) and embracing a renewed and more nuanced conceptualization of conformity suggesting that "acts of differentiation are acts of conformity on dimensions of difference used by an audience" (Zuckerman, 2016), the original question on the conformitydistinctiveness tension in family firms can be resolved by focusing on who family firms conform to and what level of commitment they show in responding to external pressures 
compared to their nonfamily counterparts. Drawing on these insights, we suggest that family members' specific concerns with family-centered noneconomic goals - including deriving a sense of identity from the firm, receiving social acceptance and recognition, maintaining reputation, and enjoying status in the field (Berrone et al., 2010; Kotlar \& De Massis, 2013) engender different rationales to conform to the behavior of other firms to avoid social losses, but also greater motivation and commitment to engage in legitimized behaviors to solidify the firm's social standing in the eyes of external constituents.

Specifically, we argue that firms conform selectively by modulating their propensity to conform depending on the categorical affiliation defined by external audiences and their selfidentification with a given category to preserve their social wealth - conceived as the perceived endowment that the firm derives from fulfilling the expectations of a social system, in terms of values, norms, beliefs, and meanings - and/or access the economic benefits associated with selective conformity (Westphal \& Bednar, 2008). We theorize different underlying rationales for conformity and focus on two in particular - conformity-indistinctiveness and distinctiveness-in-conformity - analyzing their prominence in family versus nonfamily firms. Conformity-in-distinctiveness occurs when firms with distinctive traits or attributes adhere more favorably to a behavior in their industry because their closest peers, or in-group members, have done the same. In contrast, distinctiveness-in-conformity occurs when firms align more favorably with a behavior when it is widespread among industry peers with attributes that depart from those featured by their closest peers. We suggest that family firms' desire to preserve social wealth will lead them to follow a conformity-in-distinctiveness rationale, whereas nonfamily firms will seek positive recognition by conforming to a group of industry peers with distinctive features to accrue economic rewards from their distinctiveness-in-conformity. Moreover, as family firms are more vulnerable to negative assessments by relevant others and place greater value on 
achieving legitimacy aside from any economic gains (Berrone et al., 2010), we argue that they are caught in a motivational asymmetry, such that propensity to conform will trigger more substantive behavioral responses in family firms than in nonfamily firms.

Analyses with longitudinal data on new product introductions in a representative sample of Spanish manufacturing firms between 1998 and 2012 support our theoretical model, providing three contributions to the literature. First, we advance understanding of how family firms selectively navigate pressures to conform by exploiting the complementary explanatory power of the behavioral agency model and institutional theory. In doing so, we respond to recent calls for multi-theory approaches to fully understand family firm behavior (Miller \& Le Breton-Miller, 2014). Second, we address concerns that current institutional theories do not fully explain variations in responses to institutional pressures (e.g., Berrone et al., 2010; Martins, 2005) by testing alternative mechanisms underlying conformity and showing that family and nonfamily firms respond heterogeneously to external social pressures, despite experiencing similar propensities to conform. Relatedly, we address the gap in research on conformity and distinctiveness in privately-held family firms, as most of prior research has focused on public firms where institutional pressures tend to prevail over the private interests of family owners and managers (e.g., Berrone et al., 2010; Engel, Hack, \& Kellermanns, 2015; Miller et al., 2013). Finally, we contribute to literature on innovation in family firms by suggesting that conformity pressures help maximize their innovation efficiency (Duran et al., 2015; Patel \& Chrisman, 2014).

\section{THEORY DEVELOPMENT AND HYPOTHESES}

\section{Conformity, Distinctiveness and New Product Introduction in Family Firms}

The conformity-distinctiveness debate is particularly apparent in the context of innovation strategy. Firms introduce product innovations to move into new industries and try out new technologies, thereby facing substantial economic uncertainty (Greve \& Taylor, 
2000). At the same time, the introduction of a product innovation is a highly visible behavior that can trigger either positive or negative social assessments (Aldrich \& Fiol, 1994).

The behavioral agency model explains how loss-averse managers process information under conditions of risk and uncertainty (Wiseman \& Gomez-Mejia, 1998), suggesting that they are less concerned with maximizing future financial wealth than minimizing losses to present financial wealth, thereby protecting perceived wealth or reversing anticipated losses even at the expense of accepting greater risk (Wiseman \& Gómez-Mejía, 1998). Extending the behavioral agency model to family firms, scholars have argued that family managers frame strategic choices depending on how these choices will affect the family's accumulated stock of social, affective and emotional endowments deriving from the family's controlling position in the firm, collectively labeled socioemotional wealth (SEW) (Gomez-Mejia et al., 2007), such that family firms are willing to bear greater economic risk and forgo potential financial gains to preserve their SEW. Hence, family firms are likely to bear the risk and uncertainty associated with new product introduction only if driven by the belief that such risk will be counterbalanced by the preservation of current SEW, leading to divergent behaviors and choices (Gomez-Mejia et al., 2007). ${ }^{1}$

Institutional theory provides an alternative explanation. This perspective emphasizes similarity vs. heterogeneity across organizations and within specific organizational fields (Ansari, Fiss, \& Zajac, 2010; Deephouse, 1996, 1999), suggesting that to discern between legitimate and illegitimate organizations, external actors evaluate organizations through their displays of conformity (Bitektine, 2011; DiMaggio \& Powell, 1983). At the same time, they focus on what makes an organization different from others via social comparison to express

\footnotetext{
${ }^{1}$ New product introductions may also occur in response to industry normative prescriptions and social expectations that go beyond internal managerial preferences. Focusing on compliance with unequivocal environmental rules that have certain social benefits Berrone et al. (2010) show that family firms tend to substantively comply with institutional demands. Yet this behavior may not extend to the case of new product introductions that have uncertain social and economic benefits (Schoonhoven, Eisenhardt, \& Lyman, 1990).
} 
judgments on the specific behavioral attributes of firms and their ability to create value, i.e., their reputation (Deephouse \& Carter, 2005; Whetten \& Mackey, 2002). In this view, a new product introduction is driven by growing pressures for social conformity and legitimacy concerns, leading managers to behave according to taken-for-granted assumptions rather than conscious strategic choices (DiMaggio \& Powell, 1983: 149). Scholars applying this perspective to family firms argue that their noneconomic goals and particularistic behaviors make them particularly unconventional in the eyes of outside stakeholders, creating powerful pressures to conform that transcend any single organization's purposive control (Bertrand \& Schoar, 2006; Miller et al., 2013). For example, Miller et al. (2013) show that publicly traded family firms conform more assiduously along visible strategic dimensions. Also, a recent study by Engel et al. (2015) highlights that listed German family firms are more likely to adopt performance-related pay than other firms, even if this is not in line with family noneconomic goals. However, existing studies tend to treat conformity as a passive and monolithic response to external or institutional pressures, offering only limited insights into how social pressures may drive family firm motivations and propensity to engage in new product introduction. Table 1 offers an overview of the differences in focus between the behavioral agency model and institutional theory and their predictions about family firms' responses to internal and external expectations.

\section{Insert Table 1 about here}

The divergence in focus between these theoretical perspectives highlights i) the external social environment's active role in influencing managerial perceptions of loss and gain that behavioral agency theorists need to consider to understand risky choices going beyond purely economic considerations (Greve \& Teh, 2017), and ii) the important role of managerial cognition, goals and preferences that institutional theorists need to acknowledge to graft a comprehensive model of strategic responses to external pressures. These complementary gaps 
are even more evident in comparing findings in family business literature applying the behavioral agency model and institutional theory. Variations in the family's stock of SEW depend on fulfilling the expectations of external audiences. In particular, positive social judgments may facilitate the controlling family achieving an idiosyncratic set of "socially worthy" noneconomic preferences (Berrone et al., 2010: 86). At the same time, family firms are a social reality and the social pressure exerted by stable widespread agreements on category meaning is a central tenet of research applying institutional theory. Thus, irrespective of the single organization's goals and preferences, family firms will be subject to targeted social pressures (e.g., Engel et al., 2015; Miller et al., 2013) and will be more concerned with negative assessments of relevant others when considering the introduction of a new product.

\section{Balancing Conformity and Distinctiveness: Four Different Rationales for Conformity}

Some recent work has started exploring the complementarities between the behavioral agency and institutional theory perspectives proposing a more agent-based and cognitive view of conformity (e.g., George et al., 2006; Sharkey \& Bromley, 2015). Recent research has shown that firms may have different propensities to conform and varying ways of doing so depending on whether they are more likely to see conformity as a way to avoid the threat of social disapproval and delegitimation or pursue the opportunity to reap the social gains associated with quality recognition (Durand \& Kremp, 2016; Kennedy \& Fiss, 2009). These motivational drivers for conformity depend on firm membership in one or multiple social categories (Cattani, Porac, \& Thomas, 2017; Vergne \& Wry, 2014) that segment and order the social structure of a field or industry, as well as firm owners' and managers' concerns for their own and their firm's social identity (Leonardelli et al., 2011; Vergne \& Wry, 2014). For example, Zhao et al. (2016) have recently suggested that conformity and distinctiveness are not necessarily mutually exclusive and optimal distinctiveness rests on the constant interplay 
between managerial agency and stakeholder evaluation. Firms striving for optimal distinctiveness need to adapt to different and heterogeneous evaluation frameworks and be attuned to which organizational attributes external audiences use as dimensions of difference (Zhao et al., 2016).

To theorize about these dimensions, we draw on the basic assumption that external stakeholders and audiences observe or impute to each firm certain characteristics based on visible aspects of behavior used as cues to enable themselves to answer questions about the firm's identity (Vergne \& Wry, 2014). These observed or imputed characteristics are then related to and interpreted in terms of a set of social categories (Zuckerman, 2016) that "represent a specific kind of collective typification, where audiences have abstracted from the uniqueness of individual organizations to form a type of similar organizations" (Cattani, Porac, \& Thomas, 2017: 71). Corresponding to different social categories are differing sets of expectations that both enable and constrain managerial strategic choices and organizational responses (Durand \& Paolella, 2013). Social categories, in turn, vary in their level of distinctiveness, which we refer to as the clarity and impermeability of the boundaries defining a given sub-group within a super-group and differentiating it from other out-groups at the same hierarchical level (Leonardelli et al., 2011). Based on the level of distinctiveness of a given social category to which a firm is assigned and the level of exclusiveness of a practice or behavior to such social category, we identify four different rationales for conformity as illustrated in Figure 1.

\section{Insert Figure 1 about here}

Conformity-in-conformity occurs when members of an inclusive group increase their propensity to follow a given behavior or adopt a given practice when the exclusiveness of such behavior to their own social category increases, which means when such behavior or practice is prevalently widespread among other in-group members. By contrast, 
distinctiveness-in-conformity occurs when members of an inclusive group increase their likelihood to follow a given behavior when the proportion of in-group members enacting it decreases. Conformity-in-distinctiveness occurs when members of a distinct social group show a heightened propensity to engage in a behavior that is prevalently widespread among other in-group members. Finally, the members of distinct social categories that increase their propensity to engage in a behavior when the proportion of in-group members enacting it relative to out-group members decreases follow a distinctiveness-in-distinctiveness rationale for conformity. At the group-level, these rationales are incompatible and respond to different social motivations. In particular, conformity-in-conformity and conformity-in-distinctiveness primarily reflect the desire to avoid social losses due to being out of step with what has become legitimate within slightly and highly distinct social categories respectively. Members of slightly and highly distinct social categories who instead seek to improve their social standing and gain recognition by distinguishing themselves from other in-group members respectively follow the distinctiveness-in-conformity and distinctiveness-in-distinctiveness rationales.

However, we expect that not all these rationales are equally likely. The more a group is perceived as distinct, the easier it will be for external audiences to benchmark category members' behaviors against the prevailing categorical membership norms and hence the greater the pressure experienced by group members to abide by these norms, embracing a conformity-in-distinctiveness rationale (Bitektine, 2011; Durand \& Paolella, 2013; Vergne \& Wry, 2014). On the other hand, members of slightly distinct groups will face milder pressures to demonstrate compliance with categorical membership norms due to the absence of sufficiently impermeable category boundaries that allow external audiences to form clear expectations and exert conformity pressures within the social category (Vergne \& Wry, 2014). They will instead perceive the need to gain visibility and social recognition by 
differentiating from other group members through distinctiveness-in-conformity (Leonardelli et al., 2011). In addition, a firm's propensity to conform selectively will be affected by selfcategorization and subsequent self-identification within a given social category (Lounsbury \& Glynn, 2001; Leonardelli et al., 2011). Social identity theory suggests that a firm's tendency to identify with a group leads to adherence to group norms and homogeneity in attitudes and behavior (Ashforth \& Mael, 1989).

\section{Varying Propensities to Conform in Family and Nonfamily Firms}

As family firms are largely perceived as having particularistic goals (Gomez-Mejia et al., 2007), distinct governance structures (Miller et al., 2013) and resources (Habbershon \& Williams, 1999), the presence of a controlling family and the active involvement of family members in ownership and management are often viewed as a distinct approach to business in the eyes of key stakeholders (Chua, Chrisman, \& Sharma, 1999). The stereotypical family firm is assumed to be owned and managed by a group of family members, where the firm's objectives are closely-linked to those of the family (Miller et al., 2013). As a consequence, audience members are likely to use family involvement in ownership and management as a relevant feature or segregating criterion, for grouping firms. As the family firm category is sufficiently marked in audience members' mental models (Durand \& Paolella, 2013), external constituents can construct beliefs about the behavior of family firms based on the behavioral dynamics emerging in the category. As a result, family firms may become particularly attentive and responsive to the behavior exhibited by other family firms to avoid social losses due to misalignment with other in-group members (Hannan, 2010).

Attention to other family firms' behaviors can also be driven by family members' identification of the firm as a family firm (Zuckerman, 2016). Indeed, research on social identification in organizations suggests that a firm's tendency to identify with a group is facilitated by the distinctiveness of the group's attributes (Ashforth \& Mael, 1989; 
Leonardelli et al., 2011). Accordingly, prior studies have repeatedly shown that family owners and managers identify more strongly with their firm than nonfamily members (Deephouse \& Jaskiewicz, 2013). Thus, family firms are likely to experience a heightened need for in-group assimilation and inclusion that translates into increased propensity to conform. For instance, Fourné and Zschoche (2015) have shown that family firms attend to the behaviors of an idiosyncratic peer group that consists of family firm competitors. We thus suggest that when a product innovation has been predominantly introduced by family firms, other family firms may feel compelled to do the same, which is consistent with the conformity-in-distinctiveness rationale. This occurs because behaving differently from other family firms will increase the risk of incurring negative evaluations or being deemed unacceptable by outside constituents, jeopardizing their "socially worthy" noneconomic goals and eroding the family's SEW. As such, the decision to introduce a new product will be largely driven by legitimacy concerns, with less consideration given to the economic implications.

On the other hand, since nonfamily firms represent a less distinct social category, they are likely to experience less pressures to follow categorical membership norms, thereby being less conditioned in their decisions by social expectations and evaluations. Perhaps more importantly, nonfamily firms are less concerned with preserving firm legitimacy in itself and are likely to pay more attention to the economic implications of improving their social standing in the eyes of external stakeholders. As a result, nonfamily firms will more likely engage in behaviors that will possibly enhance both positive social evaluations and economic profits. Extending this logic to new product introductions, nonfamily firms will see the widespread introduction of a product innovation among family firms as an opportunity to gain visibility through association with family firms and thus increase the standing of their own firm in the industry by constituting themselves as "exemplary users" of the innovation in 
their social group (Compagni, Mele, \& Ravasi, 2015). This effect will be especially strong when other nonfamily firms have not yet adopted the product innovation. Therefore, nonfamily firms will be more likely to modulate their propensity to conform self-servingly by following strategic recipes less closely to their own social category through a distinctivenessin-conformity rationale (Deephouse, 1999).

H1: As the exclusiveness of product innovation introductions to the focal firm's ownership-based category increases, the likelihood of introducing a product innovation increases in family firms, whereas it decreases in nonfamily firms.

In addition to ownership-based social categories, geographic boundaries also matter in audience members' mental models, with geographical regions exhibiting "overarching" features that make them "durably distinct" (Molotch, Freudenburg, \& Paulsen, 2000). Collectivities of geographically proximate and interdependent firms produce social identities resulting in shared norms, values and rules that exercise pressures on resident firms. Such norms are institutionalized through patterns of social and professional interactions, and generally accepted rules of the game that evolved over time (Pouder \& St. John, 1996). In other words, local understanding, norms, and rules may serve to legitimize firm behavior (Marquis, Glynn, \& Davis, 2007). Hence, the adoption of a conformity-in-distinctiveness rationale will be likely among firms operating in the same geographic region, as members of a common group characterized by a high degree of distinctiveness. Prior studies suggested that stakeholders tend to be segmented by geographic location, adopting unique logics and evaluative frameworks when judging firms and their legitimacy (Zhao et al., 2016). Greater social monitoring and exposure to audience members' assessments at the local level will give rise to intense community pressures (Berrone et al., 2010) and discourage firms from deviating at the local level. As a result, the threat of losing legitimacy will lead family and nonfamily firms to conform to region-based group membership norms as a way of avoiding sanctions. 
However, community pressures are not uniform in their influence across resident firms. Greenwood et al. (2010) showed that although community effects on firm decisions influence all firms at the regional level, family firms are more willing to compromise their economic decisions to favor the community's interest. At the regional level, where a firm's visibility is relatively high and its conduct often subject to public scrutiny and media attention, family firms are likely to have a greater incentive to introduce a product innovation when other regional firms in the industry have done so, because the threat of delegitimation and the loss resulting from non-conformity loom larger due to the desire to preserve the family's SEW (Berrone et al., 2010). By aligning with other firms in the region, family firms demonstrate their bona fides as community members and avoid sanctions and distrust from regional elites (Berrone et al., 2010; Greenwood et al., 2010). What is more, at the local level, family owners and managers tend to have strong social ties with their customers, suppliers, and bankers that become part of the stock of SEW to be preserved and transferred across generations (Miller \& Le Breton-Miller, 2005). Such social embeddedness within the community engenders a stronger sense of shared in-group identity in family firms that may lead to lock-in, generating loyalty from family members to the region-based group's values and norms, and preventing them from attending to threats and opportunities beyond the boundaries of the group.

On the other hand, as nonfamily firms are more concerned with anticipating the financial gains deriving from engaging in new product introduction as an externally validated and accepted behavior, we expect that at the regional level, nonfamily managers will try to position their firm to avoid social losses that could impair the firm's current financial wealth and, at the same time, increase the likelihood of reaping future financial gains (Deephouse, 1999). As a result, the tendency to abide by region-based categorical norms and follow a conformity-in-distinctiveness rationale will be weaker in nonfamily firms, especially when 
they perceive that distinguishing themselves from other regional peers will not impair their firm's current stock of financial wealth and will instead yield future financial gains. When this occurs, nonfamily firms may even opt for a distinctiveness-in-distinctiveness rationale. For example, Compagni, Mele, \& Ravasi (2015) examined the diffusion of robotic surgery in the Italian healthcare system, showing that some firms framed the introduction of robotic surgery as an opportunity to the extent that its adoption would have helped them distinguish themselves from a geographically defined subset of comparable firms.

H2: As the exclusiveness of product innovation introductions to the focal firm's regionbased category increases, the likelihood of introducing a product innovation increases more in family firms than in nonfamily firms.

\section{Propensity to Conform and Behavioral Responses}

By adopting a given product innovation, firms demonstrate compliance with membership norms and ensure their legitimacy in the eyes of external constituents. However, pure alignment with membership norms rarely enables decision makers to gain recognition and improve their firm's reputation: the more aligned an organization, the less it can stand out and gain recognition as a producer of quality (Deephouse \& Carter, 2005; Durand \& Kremp, 2016). While nonfamily firms following a distinctiveness-in-conformity rationale can reap social benefits from improving their social standing in the group of closest peers, family firms following a conformity-in-distinctiveness rationale may struggle to achieve social gains in the form of recognizability of their offering, albeit forestalling the threat of a social loss. Thus, to be attested and rewarded as producers of quality, they need to send signals to audience members about their firm's ability to provide value compared to their peers and rivals (Philippe \& Durand, 2011). As a result, family firms will work more feverishly to solidify their social standing in the industry, using conformity to increase their reputation in the eyes of key constituents (Miller et al., 2013). Recent studies have shown that heightened identification between the family and the firm motivates family members to pursue social 
gains, such as quality recognition and reputation (Deephouse \& Jaskiewicz, 2013). This leads to behaviors that demonstrate the congruence of the family firms' actual actions with their expected behavior through substantive responses to institutional demands.

For example, Kammerlander and Ganter (2015) showed that the pursuit of social gains in terms of improvements in the firm's reputation fostered a pattern of highly intense adoption. Therefore, although family and nonfamily firms may experience similar propensities to conform by introducing a widespread product innovation among in-group or out-group members, such propensities may translate into more substantive actions and higher innovative outputs in family firms (Berrone et al., 2010). The positive perceptions of the social value of engaging in product innovation in family firms can have an "actiongenerating" effect that facilitates not only the initial adoption of the practice but also its effectuation (Tolbert \& Zucker, 1983). Additionally, the greater discretion to dispose, direct and allocate firm resources (Carney, 2005) is likely to entail superior ability to translate propensity to conform into actual responses (Chrisman et al., 2015) when such responses emphasize the congruence between the firm's values and actions and those deemed appropriate by relevant stakeholders (Philippe \& Durand, 2011). Conversely, nonfamily firms will have weak interest in enacting bold responses, especially when associated with unpredictable economic benefits, since the returns from the adoption of a distinctiveness-inconformity rationale will be sufficient to garner visibility and access critical resources (Westphal \& Zajac, 1998).

H3: The relationship between propensity to conform and number of new product introductions is stronger in family firms than in nonfamily firms.

\section{METHODS}

\section{Sample}

Our sample includes 2,338 Spanish manufacturing firms between 1998 and 2012, resulting in 12,426 firm-year observations across 20 manufacturing industries. Product 
innovation data derive from the Encuesta Sobre Estrategias Empresariales (ESEE), a survey on business strategies assembled annually by the Spanish Fundacion Empresa Publica (Public Firm Foundation) through its Economics Research Program. All major manufacturing subsectors in NACE-CLIO R44 (the industry classification scheme commonly adopted in Europe) are represented. The focus on manufacturing industries is considered appropriate in the context of product innovations and conformity. Additionally, as regional communities are particularly pronounced in Spain, with the Constitution recognizing 17 historic regions, the Spanish context is particularly apt to investigate the influence of region-based categorical membership on the decision to introduce a product innovation (Greenwood et al., 2010).

\section{Dependent Variables}

Likelihood to Introduce a Product Innovation. We used a dummy variable capturing whether or not a firm introduced innovations in product functionalities and/or design features that are clearly visible to audience members - in a given industry at time t. Visibility is a fundamental characteristic of an innovation that allows the firm to show its conformity and signal or prove its commitment to high quality.

Number of New Products. A new product was defined as the introduction of an entirely new product showing changes in design characteristics and/or functionalities at $t+1$ (Katila, 2002). Thus, products incorporating only new components and materials did not qualify as a new product.

\section{Independent Variables}

Family Firm. Following Greenwood et al. (2010), we used a binary measure of family firms distinguishing family firms $(=1)$ from nonfamily firms $(=0)$ based on majority ownership (>50\%) and family involvement in management (e.g., Chrisman \& Patel, 2012). As a robustness check, we also used an objective measure of family involvement in terms of 
number of owners and owner's relatives occupying top managerial positions in year t-1 (e.g., Kotlar et al., 2013). Results remained largely the same under this specification.

Ownership-based Exclusiveness. To compute our measure, we calculated the number of other firms operating in the same industry as the focal firm in year t-1 with the same type of ownership that introduced at least one product innovation between year $\mathrm{t}-3$ and $\mathrm{t}-1$, divided by the total number of firms that introduced at least one product innovation between year $\mathrm{t}-3$ and $\mathrm{t}-1$ in the industry, excluding the focal firm. We adopted two ownership categories based on the identity of shareholders holding 50 percent or more of company stock: family ownership and nonfamily ownership. We controlled for changes in ownership and industry by the focal organization between year $\mathrm{t}-1$ and the current year. As a robustness check, we also ran our regressions using four ownership categories to define ownership-based groups: family ownership, (nonfamily) foreign ownership, state ownership, and mixed investors ownership. Results were largely consistent.

Region-based Exclusiveness. To construct this measure, we coded each firm as located in one of Spain's 17 regions. We then calculated the number of other firms operating in the same region and industry as the focal firm in year t- 1 having introduced at least one product innovation between year $\mathrm{t}-3$ and $\mathrm{t}-1$ divided by the total number of firms that introduced at least one product innovation between year $\mathrm{t}-3$ and $\mathrm{t}-1$ in the industry, excluding the focal firm. We controlled for changes in location and industry by the focal firm between year t-1 and the current year. Although we considered three years a reasonable period for an innovation to serve as a model for other firms, we tested the sensitivity of our results by estimating the models using other frequently-used time windows and confirming the robustness of our findings for two-, three- and four-year windows.

Propensity to Conform. This explanatory variable to test H3 was derived from the model estimating the Likelihood to Introduce a Product Innovation as a firm's marginal probability 
of introducing a product innovation at time $t$ in response to prior new product introductions by ownership-based and region-based group members.

\section{Control Variables}

We included several firm- and industry-level control variables lagged at $\mathrm{t}-1$. We used Number of Adopters and their Average Performance to isolate "economically based rational accounts" for the decision to introduce a product innovation (Ansari, Fiss, \& Zajac, 2010). Number of Adopters was a count variable capturing the number of all other firms adopting at least one innovation in the product's design/functionalities in the prior three years and operating in the same industry as the focal firm. Adopters' Average Performance was the average return on assets (ROA) of all other firms in the same industry as the focal firm introducing at least one product innovation in the prior three years. The introduction of a Product Innovation in year t-1 was included to capture learning effects (e.g., Srinivisan, Haunschild, \& Grewal, 2007). Consistent with prior research (Greve, 2003), we also included Performance Feedback measured as the discrepancy between a firm's ROA in year t-1 and the average ROA of firms in the manufacturing sector in year t-2, and the Slack Index based on the standardized mean of absorbed (working capital to sales ratio), unabsorbed (current assets to current liabilities ratio), and potential slack (equity to debt ratio). The lagged $R \& D$ Intensity controlled for routinized allocation of resources to R\&D. The firm's technical expertise was accounted as the total Number of Patents granted to a firm in year t-1 (Srinivasan et al., 2007). Product Diversification was coded 1 if the organization offered more than one product across different manufacturing subsectors in year $\mathrm{t}-1$, otherwise 0 (Katila, 2002). Following prior studies, we used Firm Age (years since incorporation) to control for the possibility of entrenchment in family firms (Chrisman \& Patel, 2012). We controlled for Firm Size using the log of sales. At the industry-level, we included two timevarying variables capturing the level of environmental uncertainty and competition in year t- 
1, respectively. Environmental Uncertainty was measured as the change in the industry concentration ratio, accounted for by the four largest firms between year $\mathrm{t}-2$ and $\mathrm{t}-1$. Competition was measured as the industry density in year $\mathrm{t}-1$. At the region-level, we included a time varying variable Family Firms Regional Presence capturing the number of family firms operating in the same region as the focal firm in year $t-1$. Year effects were included in all models, but the coefficients are not reported in the tables.

Endogeneity. Since firms may introduce product innovations as a consequence of unobservable organizational or environmental characteristics not captured in the control variables, we used the Heckman two-stage procedure including the inverse Mill's ratio in the models as a control variable (Shaver, 1998). We estimated a probit model for each period where the family firm is the endogenous variable (see, for example, Gomez-Mejia et al., 2007; Kotlar et al., 2014). We then estimated the likelihood of a firm introducing a product innovation and number of new products using the inverse Mill's ratio from the first stage as a control variable. In the first-stage model, we used five variables that could influence the attractiveness of continued family ownership and management, but not the decision to introduce a product innovation: the number of family members working as employees in the firm, whether the firm was privately listed, whether it was part of a corporate group or a cooperative, and the share of foreign equity. Firm age, size, year and industry dummies were also included in the first-stage model.

\section{Analytical Approach}

When analyzing panel data in which events occur repeatedly at discrete points in time, pooled cross-sectional logistic regression is the preferred method for event history analysis as it can handle tied events without making assumptions about the exact timing of an event (Allison, 1984; Yamaguchi, 1991). We expressed the logistic regression as a latent response model relating the dichotomous observed response (introduction of a product innovation $y$ ) to 
a latent variable representing a firm's propensity to introduce a product innovation $\left(y^{*}\right)$ using a threshold model. To relax the assumption of conditional independence among the responses for the same firm given the covariates, we implemented a three-level random intercept logistic model with time-points (level $\mathrm{i}^{(1)}$ ) nested in firms $\left(\right.$ level $\left.\mathrm{j}^{(2)}\right)$, nested in industries (level $\left.\mathrm{k}^{(3)}\right)$, a form of generalized linear mixed model (GLMM) which enables the overall level of firm propensity to introduce a product innovation to vary between clusters $\mathrm{j}$ and $\mathrm{k}$ below and above the variability explained by the covariates (Rabe-Hesketh, Skrondal, \& Pickles, 2005). The industry-level random intercept induces dependence among firms in the same industry and the firm-level random intercept induces additional dependence among observations on the same firm. We specified the linear regression model for the latent response $y_{i j k}^{*}$ as follows:

$y_{i j k}^{*}=\alpha f_{j}+\beta^{\prime} z_{i-1 j k}+\gamma^{\prime} f_{j} z_{i-1 j k}+\delta^{\prime} \boldsymbol{x}_{i-1 j k}+\zeta_{j k}^{(2)}+\zeta_{k}^{(3)}+\varepsilon_{i j k}$

Where $f_{j}$ is our family firm variable, $z_{i-1 / k}$ is a vector of variables describing the exclusiveness of product introduction to the focal firm's ownership- and social-based groups. Vector $x_{i-1 j k}$ includes our control variables, $\zeta_{j k}^{(2)} \sim N\left(0, \psi^{(2)}\right)$ and $\zeta_{k}^{(3)} \sim N\left(0, \psi^{(3)}\right)$ are the random intercepts, and $\varepsilon_{i j k} \sim N(0,1)$ is an error term. $\zeta_{j k}^{(2)}, \zeta_{k}^{(3)}$ and $\varepsilon_{i j k}$ are mutually independent, and independent of the explanatory variables. Our coefficients of interest are the sets $\beta^{\prime}$ and $\gamma^{\prime}$ that represent the propensity to conform of nonfamily and family firms respectively based on the exclusiveness of new product introductions to the focal firm's ownership- and region-based groups. To relax the assumption of independence of observations and obtain asymptotically consistent estimates even with heteroskedastic errors, we estimated robust standard errors using the Huber/White sandwich estimator. Hence, we estimated the average marginal probabilities to conform across family and nonfamily firms that we used as covariates in the model predicting number of new products (Gomez-Mejia et 
al., 2007). To estimate the number of new products, we used a panel Poisson regression. The generalized estimating equations (GEE) regression method enables accounting for autocorrelation due to repeated yearly measures of the same firms and is common in new product introduction studies (e.g., Katila \& Ahuja, 2002). To account for any over-dispersion in the data, we report the results with robust standard errors.

\section{RESULTS}

Descriptive statistics and correlation matrix for the variables across all years are presented in Table 2. Correlations between the various independent variables are all quite low. The highest correlation was -0.61 between ownership-based exclusiveness and family firm. Variance inflation factors for the independent variables in our models were below 2.5 on average and individually below the suggested threshold of 10 , indicating that multicollinearity was not a concern in the regressions.

\section{Insert Table 2 about here}

The results of our generalized linear mixed model predicting a firm's likelihood to introduce a product innovation are shown in Table 3. The results must be interpreted conditionally on the random intercepts as random-intercept logistic regression fits subjectspecific or conditional probabilities for individual firms and industries. Model 1 includes the estimates for the control variables and serves as our baseline specification. The positive and significant coefficient for the number of prior adopters $(\beta=0.02, p<.001)$ supports the view of institutional theory that widespread adoption of a practice contributes to its perceived legitimacy, thus creating normative pressures to adopt (DiMaggio \& Powell, 1983). Conversely, we found no significant effect of the average performance of prior innovators on the likelihood of a firm introducing the product innovation (Haunschild \& Miner, 1997).

As the results across Models 2-5 were consistent in significance, only the full model, Model 5, is interpreted. The coefficient of the family firm variable was negative and 
significant $(\beta=-1.09, \mathrm{p}<.01)$, suggesting that the likelihood of a family firm introducing a new product design or functionality in a given industry and year was 0.34 times $^{2}$ that of a nonfamily firm in the same industry and year. We also found a negative and significant relationship between ownership-based exclusiveness of new product introductions and the likelihood of the focal firm introducing a product innovation $(\beta=-1.18, \mathrm{p}<.01)$. This result supports our prediction that nonfamily firm decision makers follow a distinctiveness-inconformity rationale and are more inclined to conform to the behavior of other firms with dissimilar ownership; whereas an increase in the proportion of peers belonging to their firm's ownership category among prior innovators negatively affects their propensity to introduce the product innovation. The coefficient of the region-based exclusiveness variable was negative and not statistically significant, providing no evidence of a conformity-indistinctiveness rationale among nonfamily firms within region-based groups, and pointing instead to distinctiveness-in-distinctiveness.

The coefficient of the interaction between family firm and ownership-based exclusiveness was positive and statistically significant $(\beta=1.27, \mathrm{p}<.05)$, indicating that family firms are more sensitive to the actions of other family firms than those of nonfamily firms. The coefficient of the interaction between family firm and region-based exclusiveness is also positive and marginally significant $(\beta=1.00, \mathrm{p}<.10)$ : the likelihood of a firm introducing a product innovation in response to an increase in the proportion of innovators operating in the same region is greater if the firm is family owned and managed. Taken together, these results provide support for $\mathrm{H} 1$ and marginal support for $\mathrm{H} 2$. To better interpret these results, in Figures 1 and 2, we present the predictive margins of the two interaction effects by plotting the population-averaged or predicted marginal probabilities of introducing a product innovation against the levels of ownership-based exclusiveness (Figure 1) and region-based

$2=\exp (-1.09)$ 
exclusiveness (Figure 2) for family and nonfamily firms. As predicted, Figure 1 shows that while in family firms the increase in the number of firms in their same ownership category that introduced a product innovation in the past has a positive effect on the probability of the focal firm introducing the product innovation, in nonfamily firms this relationship is negative. Figure 2 shows that when the proportion of firms in the focal firm's region-based group that introduced a product innovation in the prior three years increases, the slope of the regression line increases for family firms (dotted line) and decreases for nonfamily firms (solid line). Aside from indicating that family firms are more likely to abide by norms among peers located within the boundaries of their regional community, it points to a tendency in nonfamily firms to embrace a distinctiveness-in-distinctiveness rationale for conformity at the regional community-level.

\section{Insert Table 3, Figure 2 and Figure 3 about here}

Table 4 presents the results of the GEE Poisson regression analysis and tests $\mathrm{H} 3$ in relation to a firm's propensity to conform at time $t$ to the number of new products at $t+1$ in family versus nonfamily firms. The first column reports the baseline model. In Model 2, we introduced the propensity to conform at time $t$ and the family variable, and in Model 3 , we included the interaction between propensity to conform and family firm. H3, proposing a positive moderating effect of family involvement in ownership and management on the relationship between a firm's propensity to conform and the number of new products, finds support in Model $3(\beta=1.78, p<.01)$. Although the active involvement of family members in firm ownership and management has a negative effect on the number of new product introductions $(\beta=-0.78, \mathrm{p}<.05)$, it reinforces the positive effect of propensity to conform on the number of new product introductions. 


\section{Insert Table 4 about here}

Since prior research has found different responses to institutional pressures in publicly and privately held firms, we conducted a post-hoc analysis to test the behavior of private and public firms separately. While the findings for the sub-sample of privately held firms were largely consistent in magnitude, direction, and significance with those presented in the main analyses, for publicly held firms we found opposite results. In relation to H1, nonfamily firms embrace conformity-in-conformity by increasing their likelihood to engage in new product introductions when the proportion of nonfamily firms among prior adopters increases. Family firms embrace distinctiveness-in-distinctiveness, engaging in new product introduction with the exclusiveness of this behavior to nonfamily firms. When testing $\mathrm{H} 2$, we found that region-based audiences' expectations are extremely relevant for public firms, which at the regional level modulate their propensity to conform according to conformity-indistinctiveness. However, we found no significant differences between public family vs. nonfamily firms' responses to region-based social expectations. ${ }^{3}$

\section{DISCUSSION AND CONCLUSION}

In this paper, we attempted to integrate the behavioral agency model and institutional theory predictions to explain differences in the introduction of new product innovations due to the existence of different motivations and propensity to conform between family and nonfamily firms (Compagni et al., 2015; Fourné \& Zschoche, 2015). Drawing on contemporary developments of the concept of conformity in institutional theory and related literatures (e.g., Durand \& Kremp, 2016; Philippe \& Durand, 2011; Zhao et al., 2016), we conceived conforming behavior as a stylized fact induced by external pressure driven by the firm's typification as a member of one or more social categories (Cattani et al., 2017; Vergne

\footnotetext{
${ }^{3}$ Ownership-based Exclusiveness $t_{\mathrm{t}-1}: \beta=4.64, \mathrm{p}<.05$; Family Firm $\mathrm{t}_{\mathrm{t}-1}$ *Ownership-based Exclusiveness $\mathrm{s}_{\mathrm{t}-1}: \beta=-9.75$, $\mathrm{p}<.05$; Region-based Exclusiveness $\mathrm{t}_{-1}: \beta=3.77, \mathrm{p}<.001$. Unreported results are available from the authors upon request.
} 
\& Wry, 2014), the goals of firm owners and managers, and their identification of the firm within a given social category (Leonardelli et al., 2011). We theorized four mutually exclusive rationales for conformity that firms may follow depending on the degree of distinctiveness of the firm's social category in the eyes of external constituents, and on whether the trade-off between blending in or standing out relative to other category members tilts towards the former or the latter in the eyes of the firm's internal constituents.

Analyzing Spanish manufacturing firms and their likelihood of introducing a product innovation, we found that the avoidance of social losses takes higher priority in family firm decisions. Family managers orient their firms towards abiding by categorical membership norms, enacting behaviors aligned with those of peers, such as other family firms in the industry or industry peers operating in the same region. Conversely, nonfamily firms modulate their propensity to conform to seek quality comparisons rather than defend against the threat of social losses, trying to position themselves as different from other in-group members as legitimately as possible based on the prospect of achieving economic returns. However, our post-hoc analysis revealed that these motivations reverse in publicly held firms. Since key external stakeholders often regard public family firms with suspicion or as an unorthodox approach to business (Miller et al., 2013), the compelling need to demonstrate their bona fides and avoid being discounted as illegitimate leads family firms to deviate from their categorical membership norms and instead conform to widespread behaviors among nonfamily firms. Finally, we have shown that even when family and nonfamily firms are equally willing to conform, family firms' perception of the decision to introduce new products as socially desirable creates a stronger incentive for them to innovate.

Our study has major implications for future research across a variety of literature streams. First, it enriches and extends current family business literature by integrating behavioral agency and institutional theories to provide a better understanding of how family 
firms differ from nonfamily firms in navigating the tension between conformity and distinctiveness, and how this can help explain different strategic choices between family and nonfamily firms in terms of product innovation introductions. Differences in the way family and nonfamily firms balance conformity and differentiation from others' practices reside in the relationship between conformity and distinctiveness in family decision makers' mental models compared to their nonfamily counterparts: while distinctiveness is the antecedent of conformity in family firms, distinctiveness is the expected outcome in nonfamily firms.

Furthermore, by examining the differing effects of the propensity to conform on innovation outcomes between family and nonfamily firms, this study addresses the outstanding question in family firm research on how family firms are able to achieve higher innovation output despite lower R\&D investments (Duran et al., 2015; Patel \& Chrisman, 2014). Patel and Chrisman (2014) observed that family firms can do so by changing type of R\&D investments depending on firm performance. When firm performance exceeds expectations, family firms invest in exploitative $R \& D$ projects that reduce rather than increase the variability of sales, whereas they turn to explorative and variance-enhancing R\&D investments when their performance is below aspirations. By adapting their R\&D investment strategy more aggressively than nonfamily firms, family firms are able not only to reconcile their economic and noneconomic goals, but also increase the efficiency of their R\&D investments in a way that possibly boosts innovative outputs. Our finding that family firms show higher levels of innovation output than nonfamily firms when the decision to introduce new products is perceived as socially desirable extends and complements the work of Patel and Chrisman (2014). We show that, paradoxically, the desire to appear in conformity with norms fuels innovation in family firms, thus breaking down psychological barriers to innovation and maximizing their innovation efficiency. 
Second, by theorizing the existence of four different conformity rationales depending on the degree of distinctiveness of a given social category and the degree of exclusiveness of a practice or behavior to such social category, this study expands conformity theory with a model that applies to cases in which audiences evaluate conformity at multiple levels and along multiple dimensions. Our findings suggest that conformity is not only a response to the organizational imperative to avoid the threat of delegitimation, but also a way for firms to differentiate from peers by focusing resources on some salient attributes of their field or industry to reap a large share of the benefits from distinctiveness (e.g., Durand \& Kremp, 2016). By showing that firms modulate their propensity to conform depending on both external expectations and internal goals, our research also responds to recent calls to redirect the study of institutional and social accounts of adoption towards finer-grained mechanisms that spawn and are influenced by the heterogeneity of actors and activities that underlie apparent conformity (Lounsbury, 2007). Our findings indicate that firm behavior is guided by individual preferences and external constraints, as well as by individual perceptions of external constraints (Oliver, 1991). In other words, the combination of conformity at the super-group level (industry) with either conformity or deviation at the sub-group level (e.g., ownershipbased or region-based group) reflects how individual decision makers resolve the tension between their personal interests and the expectations of external audiences.

Third, by showing that family and nonfamily firms respond heterogeneously to external social pressures despite experiencing similar propensities to conform, our study addresses the concern in extant literature that current institutional theories do not fully answer questions on variation in responses to institutional pressures (Berrone et al., 2010; Martins, 2005). Relatedly, we show that the way in which propensity to conform translates into actual behavior is driven by existing alignment between owners' preferences and external constituents' demands. Finally, the results of the post-hoc analysis enrich the discussion on differences in 
conforming behavior between public and private firms. The few empirical studies available examining the differences in conforming behavior between family and nonfamily firms focus on publicly traded firms (e.g., Berrone et al., 2010; Engel et al., 2015; Fourné \& Zschoche, 2015; Miller et al., 2013), leaving a gap in understanding how such behavior, its underlying motivations and mechanisms vary across family and nonfamily privately held firms. Broadly speaking, our findings support the idea that publicly held firms are more concerned with avoiding social losses, seeking approval from external audiences by coalescing around the behaviors of the category of which they claim to be members.

\section{Limitations and Future Research Opportunities}

Although our theoretical arguments are based on social accounts for the adoption of a particular innovation, we cannot completely rule out rational accounts associated with maximizing economic benefits (Ansari et al., 2010). For instance, family firms could conform more favorably to region-based and ownership-based group members in the attempt to minimize search costs and reduce the risks associated with experimentation as geographic proximity and ownership similarity may be informative of the fit between the characteristics of an innovation and the needs, objectives and structures of the adopting firm. Qualitative inquiry could offer a more detailed analysis of the cognitive and motivational factors driving innovation introduction in response to external influences and pressures in family firms.

Furthermore, additional work is needed to examine the interaction between institutional demands and organizational owners' and managers' goals and preferences. For instance, future research could delve deeper into how differently family and nonfamily firms perceive and respond to internal external pressures in the presence of competing institutional logics or multiple audiences (De Massis et al., 2016; Pontikes, 2012; Zhao et al., 2016). A refinement of our model could test the importance of audience heterogeneity as a moderator of propensity to conform in family and nonfamily firms. 
Finally, although family firms represent a rather distinct category due to their motivational, cognitive and behavioral particularities, disagreement among audiences on which attributes enter the category's definition could lessen conformity pressures and free family firms to deviate from categorical membership norms. It would be interesting to investigate how family firms across different social categories modulate their propensity to conform to in-group and out-group norms. For instance, Miller et al. (2013) showed that differences in the governance roles of family members - specifically major family presence in ownership, board membership, and management especially after the first generation affect the degree of strategic conformity in family firms. Future research could refine our understanding of the antecedents and consequences of conformity and distinctiveness in family firms by investigating heterogeneity of family firm behaviors across and within different sub-groups.

\section{REFERENCES}

Aldrich, H.E., \& Fiol, C.M. (1994). Fools rush in? The institutional context of industry creation. Academy of Management Review, 19, 645-670.

Allison, P.D. (1984). Event history analysis: Regression for longitudinal event data. Beverly Hills, CA: Sage.

Ansari, S.M., Fiss, P.C., \& Zajac, E.J. (2010). Made to fit: How practices vary as they diffuse. Academy of Management Review, 35(1), 67-92.

Ashforth, B.E., \& Mael, F. (1989). Social identity theory and the organization. Academy of Management Review, 14(1), 20-39.

Berrone, P., Cruz, C., Gomez-Mejia, L.R., \& Larraza-Kintana, M. (2010). Socioemotional wealth and corporate responses to institutional pressures: Do family-controlled firms pollute less? Administrative Science Quarterly, 55(1), 82-113.

Bertrand, M., \& Schoar, A. (2006). The role of family in family firms. The Journal of Economic Perspectives, 20(2), 73-96.

Bitektine, A. (2011). Toward a theory of social judgments of organizations: The case of legitimacy, reputation, and status. Academy of Management Review, 36(1), 151-179.

Carney, M. (2005). Corporate governance and competitive advantage in family-controlled firms. Entrepreneurship Theory and Practice, 29(3), 249-265.

Cattani, G., Porac, J.F., \& Thomas, H. (2017). Categories and competition. Strategic Management Journal, 38(1), 64-92.

Chrisman, J.J., Chua, J., De Massis, A., Frattini, F., \& Wright, M. (2015). The ability and willingness paradox in family firm innovation. The Journal of Product Innovation Management, 32(3), 310-318.

Chrisman, J.J., \& Patel, P.J. (2012). Variations in R\&D investments of family and nonfamily firms: Behavioral agency and myopic loss aversion perspectives. Academy of Management Journal, 55(4), 976-997. 
Chua, J.H., Chrisman, J.J., \& Sharma, P. (1999). Defining the family business by behavior. Entrepreneurship Theory and Practice, 23(4), 19-39.

Compagni, A., Mele, V., \& Ravasi, D. (2015). How early implementations influence later adoptions of innovation: Social positioning and skill reproduction in the diffusion of robotic surgery. Academy of Management Journal, 58(1), 242-278.

De Massis, V. A., Kotlar, J., Mazzola, P., Minola, T., \& Sciascia, S. 2016. Conflicting selves: family owners' multiple goals and self-control agency problems in private firms. Entrepreneurship Theory and Practice, in press.

Deephouse, D.L. (1996). Does isomorphism legitimate? Academy of Management Journal, 39, 1024-39.

Deephouse, D.L. (1999). To be different, or to be the same? It's a question (and theory) of strategic balance. Strategic Management Journal, 20, 147-166.

Deephouse, D.L., \& Carter, S.M. (2005). An examination of differences between organizational legitimacy and organizational reputation. Journal of Management Studies, 42(2), 329-360.

Deephouse, D.L., \& Jaskiewicz, P. (2013). Do family firms have better reputations than non-family firms? An integration of socioemotional wealth and social identity theories. Journal of Management Studies, 50(3), 337-360.

DiMaggio, P., \& Powell, W.W. (1983). The iron cage revisited: Collective rationality and institutional isomorphism in organizational fields. American Sociological Review, 48(2), $147-160$.

Duran, P., Kammerlander, N., van Essen, M., \& Zellweger, T. (2015). Doing more with less: Innovation input and output in family firms. Academy of Management Journal, amj. 2014.0424.

Durand, R., \& Kremp, P.A. (2016). Classical deviation: Organizational and individual status as antecedents of conformity. Academy of Management Journal, 59(1), 65-89.

Durand, R., \& Paolella, L. (2013). Category stretching: Reorienting research on categories in strategy, entrepreneurship, and organization theory. Journal of Management Studies, 50, $1100-1123$.

Engel, P.J., Hack, A., \& Kellermanns, F.W. (2015). Setting the right mix-Analyzing outside directors' pay mix in public family firms. Journal of Family Business Strategy, 6(2), 130140.

Fiss, P.C., \& Zajac, E.J. (2004). The diffusion of ideas over contested terrain: The (non) adoption of a shareholder value orientation among German firms. Administrative Science Quarterly, 49(4), 501-534.

Fourné, S., \& Zschoche, M. (2015). Public and family firms' FDI: Patterns and performance implications of legitimacy seeking behaviors. Academy of Management Proceedings (Vol. 2015, No. 1, p. 16241). Academy of Management.

George, E., Chattopadhyay, P., Sitkin, S.B., \& Barden, J. (2006). Cognitive underpinnings of institutional persistence and change: A framing perspective. Academy of Management Review, 31(2), 347-365.

Gomez-Mejia, L.R., Haynes, K.T., Núñez-Nickel, M., Jacobson, K.J.L., \& Moyano-Fuentes, J. (2007). Socioemotional wealth and business risks in family-controlled firms: Evidence from Spanish olive oil mills. Administrative Science Quarterly, 52(1), 106-137.

Greenwood, R., Díaz, A.M., Li, S.X., \& Lorente, J.C. (2010). The multiplicity of institutional logics and the heterogeneity of organizational responses. Organization Science, 21, 521539.

Greve, H.R. (2003). A behavioral theory of R\&D expenditures and innovation: Evidence from shipbuilding. Academy of Management Journal, 46, 685-702. 
Greve, H.R., \& Taylor, A. (2000). Innovations as catalysts for organizational change: Shifts in organizational cognition and search. Administrative Science Quarterly, 45, 54-80.

Greve, H.R., Teh, D. (2017). Goal selection internally and externally: A behavioral theory of institutionalization. International Journal of Management Reviews, forthcoming.

Habbershon, T.G., \& Williams, M.L. (1999). A resource-based framework for assessing the strategic advantages of family firms. Family Business Review, 12(1), 1-25.

Hannan, M.T. (2010). Partiality of memberships in categories and audiences. Annual Review of Sociology, 36, 159-81.

Haunschild, P.R., \& Miner, A.S. (1997). Modes of interorganizational imitation: The effects of outcome salience and uncertainty. Administrative Science Quarterly, 42(3), 472-500.

Kammerlander, N., \& Ganter, M. (2015). An attention-based view of family firm adaptation to discontinuous technological change: Exploring the role of family CEOs' noneconomic goals. Journal of Product Innovation Management, 32(3), 361-383.

Katila, R. (2002). New product search over time: Past ideas in their prime? Academy of Management Journal, 45(5), 995-1010.

Katila, R., \& Ahuja, G. (2002). Something old, something new: A longitudinal study of search behavior and new product introduction. Academy of Management Journal, 45, 1183-1194.

Kennedy, M.T., \& Fiss, P.C. (2009). Institutionalization, framing, and diffusion: The logic of TQM adoption and implementation decisions among US hospitals. Academy of Management Journal, 52(5), 897-918.

Kotlar, J., \& De Massis, A. (2013). Goal setting in family firms: Goal diversity, social interactions, and collective commitment to family-centered goals. Entrepreneurship Theory and Practice, 37(6), 1263-1288.

Kotlar, J., De Massis, A., Frattini, F., Bianchi, M., \& Fang, H. (2013). Technology acquisition in family and nonfamily firms: A longitudinal analysis of Spanish manufacturing firms. Journal of Product Innovation Management, 30(6), 1073-1088.

Kotlar, J., Fang, H., De Massis, A., Frattini, F. (2014). Profitability goals, control goals, and the R\&D investment decisions of family and non-family firms. Journal of Product Innovation Management, 31(6), 1128-1145.

Leonardelli, G.J., Pickett, C.L., Joseph, J.E., \& Hess, Y.D. (2011). Optimal distinctiveness theory in nested categorization contexts: Moving from dueling identities to a dual identity. In R.M. Kramer, G.J. Leonardelli, \& R.W. Livingston (Eds.), Social Cognition, Social Identity, and Intergroup Relations: A Festschrift in Honor of Marilynn Brewer (pp. 103125). Psychology Press Festschrift series. New York, NY: Taylor \& Francis.

Lounsbury, M. (2007). A tale of two cities: Competing logics and practice variation in the professionalizing of mutual funds. Academy of Management Journal, 50, 289-307.

Lounsbury, M., \& Glynn, M.A. (2001). Cultural entrepreneurship: Stories, legitimacy, and the acquisition of resources. Strategic Management Journal, 22(6-7), 545-564.

Marquis, C., Glynn, M.A., \& Davis, G.F. (2007). Community isomorphism and corporate social action. Academy of Management Review, 32, 925-945.

Martins, L.L. (2005) A Model of the effects of reputational rankings on organizational change. Organization Science, 16, 701-720.

Miller, D., \& Chen, M.J. (1996). Nonconformity in competitive repertoires: A sociological view of markets. Social Forces, 1209-1234.

Miller, D., \& Le Breton-Miller, I. (2005). Managing for the Long Run: Lessons in Competitive Advantage from Great Family Businesses. Harvard Business School Press, Boston.

Miller, D., \& Le Breton-Miller, I. (2014). Deconstructing socioemotional wealth. Entrepreneurship Theory and Practice, 38(4), 713-720. 
Miller, D., Le Breton-Miller, I., \& Lester, R.H. (2013). Family firm governance, strategic conformity, and performance: Institutional vs. strategic perspectives. Organization Science, 24(1), 189-209.

Molotch, H., Freudenburg, W., \& Paulsen, K.E. (2000). History repeats itself, but how? City character, urban tradition, and the accomplishment of place. American Sociological Review, 791-823.

Negro, G., Hannan, M.T., \& Fassiotto, M. (2015). Category signaling and reputation. Organization Science, 26, 584-600.

Oliver, C. (1991). Strategic responses to institutional processes. Academy of Management Review, 16(1), 145-179.

Patel, P.C., \& Chrisman, J.J. (2014). Risk abatement as a strategy for R\&D investments in family firms. Strategic Management Journal, 35(4), 617-627.

Philippe, D., \& Durand, R. (2011). The impact of norm-conforming behaviors on firm reputation. Strategic Management Journal, 32(9), 969-993.

Pontikes, E.G. (2012). Two sides of the same coin: How ambiguous classification affects multiple audiences' evaluations. Administrative Science Quarterly, 57(1), 81-118.

Pouder, R., \& John, C.H.S. (1996). Hot spots and blind spots: Geographical clusters of firms and innovation. Academy of Management Review, 21(4), 1192-1225.

Rabe-Hesketh, S., Skrondal, A., \& Pickles, A. (2005). Maximum likelihood estimation of limited and discrete dependent variable models with nested random effects. Journal of Econometrics, 128(2), 301-323.

Schoonhoven, C.B., Eisenhardt, K.M., \& Lyman, K. (1990). Speeding products to market: Waiting time to first product introduction in new firms. Administrative Science Quarterly, 177-207.

Schulze, W.S., Lubatkin, M.H., Dino, R.N., \& Buchholtz, A. (2001). Agency relationships in family firms: Theory and evidence. Organization Science, 12(2), 99-116.

Sharkey, A.J., \& Bromley, P. (2015). Can ratings have indirect effects? Evidence from the organizational response to peers' environmental ratings. American Sociological Review, 80(1), 63-91.

Shaver, J.M. 1998. Accounting for endogeneity when assessing strategy performance: Does entry mode choice affect FDI Survival? Management Science, 44(4), 571-585.

Srinivasan, R., Haunschild, P., \& Grewal, R. (2007). Vicarious learning in new product introductions in the early years of a converging market. Management Science, 53(1), 1628.

Tolbert, P.S. \& Zucker, L.G. (1983). Institutional sources of change in the formal structure of organizations: The diffusion of civil service reform, 1880-1935. Administrative Science Quarterly, 28, 22-39.

Vergne, J.P., \& Wry, T. (2014). Categorizing categorization research: Review, integration, and future directions. Journal of Management Studies, 51(1), 56-94.

Yamaguchi, K. (1991). Event history analysis. Newbury Park, CA: Sage.

Westphal, J.D., \& Bednar, M.K. (2008). The pacification of institutional investors. Administrative Science Quarterly, 53(1), 29-72.

Westphal, J.D., \& Zajac, E.J. (1998). The symbolic management of stockholders: Corporate governance reforms and shareholder reactions. Administrative Science Quarterly, 127153.

Whetten, D.A., \& Mackey, A. (2002). A social actor conception of organizational identity and its implications for the study of organizational reputation. Business \& Society, 41(4), 393-414.

Wiseman, R.M., \& Gómez-Mejía, L.R. (1998). A behavioral agency model of managerial risk taking. The Academy of Management Review, 23(1), 133-153. 
Zhao, E.Y., Fisher, G., Lounsbury, M., \& Miller, D. (2016). Optimal distinctiveness: Broadening the interface between institutional theory and strategic management. Strategic Management Journal, 38(1), 93-113.

Zuckerman, E.W. (2016). Optimal distinctiveness revisited: An integrative framework for understanding the balance between differentiation and conformity in individual and organizational identities. In M.G. Pratt, M. Schultz, B.E. Ashforth, and D. Ravasi (Eds.) The Oxford Handbook of Organizational Identity. Oxford: Oxford University Press. 
Table 1

Comparison of Behavioral Agency Model and Institutional Theory and Respective Predictions on New Product Introduction in Family Firms

\begin{tabular}{|c|c|c|}
\hline & $\begin{array}{l}\text { Behavioral agency model (BAM) } \\
\text { (Wiseman and Gómez-Mejía, 1998) }\end{array}$ & $\begin{array}{l}\text { Institutional theory } \\
\text { (DiMaggio and Powell, 1983) }\end{array}$ \\
\hline Focus & $\begin{array}{ll}\text { - } & \text { Executives risk taking } \\
\text { - } & \text { Managerial self-interest } \\
\text { - Internal goals }\end{array}$ & $\begin{array}{l}\text { - Conformity as a source of legitimacy } \\
\text { - Isomorphic pressures in structured } \\
\text { fields via coercive, mimetic, and } \\
\text { normative forces }\end{array}$ \\
\hline $\begin{array}{l}\text { Level of } \\
\text { analysis }\end{array}$ & - Individual firm level & $\begin{array}{l}\text { - Organizational and organizational field } \\
\text { level }\end{array}$ \\
\hline Agency & $\begin{array}{l}\text { - Inwardly-directed agency at the } \\
\text { individual level }\end{array}$ & $\begin{array}{l}\text { - Limited externally-oriented agency at } \\
\text { the organizational level in relation with } \\
\text { the external environment }\end{array}$ \\
\hline Motivation & - Loss aversion & - External pressures \\
\hline Predictions & $\begin{array}{l}\text { - Self-interested individuals are less } \\
\text { concerned with maximizing future } \\
\text { financial wealth than minimizing } \\
\text { losses to present financial wealth, } \\
\text { thereby protecting perceived wealth or } \\
\text { reversing anticipated losses even at the } \\
\text { expenses of accepting greater risk. }\end{array}$ & $\begin{array}{l}\text { - Firms adopt practices that match } \\
\text { institutional rules and social } \\
\text { expectations }\end{array}$ \\
\hline $\begin{array}{l}\text { Application to } \\
\text { family firms }\end{array}$ & $\begin{array}{l}\text { Family firms exhibit distinctive and } \\
\text { anomalous strategic choices because } \\
\text { family managers are more concerned } \\
\text { with protecting the family's current } \\
\text { stock of socioemotional wealth rather } \\
\text { than the firm's financial wealth (e.g., } \\
\text { Chrisman \& Patel, 2012; Gomez-Mejia } \\
\text { et al., 2007; Zellweger et al., 2011). }\end{array}$ & $\begin{array}{l}\text { - The pursuit of noneconomic goals and } \\
\text { the enactment of particularistic } \\
\text { strategic choices, make family firms } \\
\text { particularly unconventional in the eyes } \\
\text { of outside stakeholders, creating } \\
\text { powerful pressures to conform (Engel } \\
\text { et al., 2015; Miller et al., 2013) }\end{array}$ \\
\hline $\begin{array}{l}\text { Predictions on } \\
\text { family firms' } \\
\text { engagement in } \\
\text { new product } \\
\text { introduction }\end{array}$ & $\begin{array}{l}\text { - Family firms will be likely to bear the } \\
\text { risk and uncertainty associated with } \\
\text { new product introduction only if they } \\
\text { believe that such risk will be necessary } \\
\text { to protect the family's stock of } \\
\text { socioemotional wealth. }\end{array}$ & $\begin{array}{l}\text { - Family firms will be likely to introduce } \\
\text { a new product if this decision } \\
\text { represents a "taken-for-granted" and } \\
\text { legitimate response to external } \\
\text { demands. }\end{array}$ \\
\hline
\end{tabular}


Table 2

Means $^{\mathrm{a}}$, Standard Deviations and Correlations ${ }^{\mathrm{b}}$

\begin{tabular}{|c|c|c|c|c|c|c|c|c|c|c|c|c|c|c|c|c|c|c|c|c|c|c|c|c|}
\hline & Variable & Mean & s. $d$. & 1 & 2 & 3 & 4 & 5 & 6 & 7 & 8 & 9 & 10 & 11 & 12 & 13 & 14 & 15 & 16 & 17 & 18 & 19 & 20 & 21 \\
\hline 1 & Number of New Products $t+1$ & 1.69 & 12.47 & 1.00 & & & & & & & & & & & & & & & & & & & & \\
\hline 2 & $\begin{array}{l}\text { Product innovation } \\
\text { introduction }\end{array}$ & 0.17 & 0.38 & 0.22 & 1.00 & & & & & & & & & & & & & & & & & & & \\
\hline 3 & Propensity to Conform & 0.16 & 0.18 & 0.17 & 0.58 & 1.00 & & & & & & & & & & & & & & & & & & \\
\hline 4 & Family Firm $t_{t-1}$ & 0.45 & 0.50 & -0.03 & -0.12 & -0.24 & 1.00 & & & & & & & & & & & & & & & & & \\
\hline 5 & $\begin{array}{l}\text { Ownership-based } \\
\text { Exclusivenesst }-1\end{array}$ & 0.55 & 0.20 & 0.01 & 0.08 & 0.17 & -0.61 & 1.00 & & & & & & & & & & & & & & & & \\
\hline 6 & $\begin{array}{l}\text { Region-based } \\
\text { Exclusiveness } t_{-1-}\end{array}$ & 0.16 & 0.15 & 0.00 & 0.07 & 0.12 & 0.00 & 0.03 & 1.00 & & & & & & & & & & & & & & & \\
\hline 7 & Number of Adopters $t_{t-1}$ & 0.13 & 0.07 & 0.01 & -0.02 & -0.02 & 0.01 & -0.03 & 0.01 & 1.00 & & & & & & & & & & & & & & \\
\hline 8 & $\begin{array}{l}\text { Adopters' Average } \\
\text { Performance } t_{t-1}\end{array}$ & 34.06 & 16.84 & 0.03 & 0.10 & 0.20 & -0.06 & 0.01 & -0.07 & -0.08 & 1.00 & & & & & & & & & & & & & \\
\hline 9 & $\begin{array}{l}\text { Product Innovation } \\
\text { Introduction } \\
t-1-1\end{array}$ & 0.22 & 0.41 & 0.19 & 0.57 & 0.88 & -0.10 & 0.08 & 0.08 & -0.03 & 0.11 & 1.00 & & & & & & & & & & & & \\
\hline 10 & $\begin{array}{l}\text { Social Performance } \\
\text { Feedback } \mathrm{t}_{\mathrm{t}-1} \leq 0\end{array}$ & -0.09 & 0.14 & -0.01 & 0.03 & 0.05 & 0.04 & -0.03 & 0.02 & -0.06 & -0.02 & 0.03 & 1.00 & & & & & & & & & & & \\
\hline 11 & $\begin{array}{l}\text { Social Performance } \\
\text { Feedback }{ }_{t-1}>0\end{array}$ & 0.08 & 0.26 & -0.02 & -0.03 & -0.05 & 0.04 & -0.03 & -0.02 & 0.07 & 0.00 & -0.03 & 0.19 & 1.00 & & & & & & & & & & \\
\hline 12 & Slack Index ${ }_{t-1}$ & 0.02 & 1.79 & 0.00 & -0.01 & -0.03 & 0.03 & 0.00 & 0.01 & -0.04 & -0.01 & -0.01 & -0.05 & -0.09 & 1.00 & & & & & & & & & \\
\hline 13 & R\&D Intensity ${ }_{t-1}$ & 0.01 & 0.02 & 0.05 & 0.18 & 0.30 & -0.08 & 0.06 & 0.06 & -0.11 & 0.03 & 0.20 & -0.01 & -0.03 & -0.01 & 1.00 & & & & & & & & \\
\hline 14 & Number of Patents $t_{t-1}$ & 0.51 & 6.16 & 0.00 & 0.03 & 0.06 & -0.04 & 0.05 & 0.09 & -0.02 & 0.05 & 0.06 & 0.00 & -0.01 & -0.01 & 0.23 & 1.00 & & & & & & & \\
\hline 15 & Product Diversification $_{t-1}$ & 0.21 & 0.56 & -0.01 & 0.05 & 0.10 & -0.01 & -0.02 & -0.03 & -0.01 & 0.05 & 0.05 & 0.00 & -0.02 & -0.01 & 0.01 & -0.01 & 1.00 & & & & & & \\
\hline 16 & Firm Age & 28.58 & 21.38 & 0.01 & 0.09 & 0.18 & -0.14 & 0.11 & 0.10 & -0.05 & 0.00 & 0.10 & 0.02 & -0.04 & 0.03 & 0.09 & 0.06 & 0.00 & 1.00 & & & & & \\
\hline 17 & Firm Size $t_{t-1}$ & 15.91 & 1.99 & 0.05 & 0.25 & 0.52 & -0.42 & 0.34 & 0.06 & -0.07 & 0.03 & 0.27 & 0.10 & -0.05 & -0.09 & 0.16 & 0.11 & 0.06 & 0.36 & 1.00 & & & & \\
\hline 18 & Market Competition ${ }_{t-1}$ & 108.42 & 51.47 & 0.00 & -0.05 & -0.09 & 0.09 & -0.12 & -0.11 & -0.06 & 0.59 & -0.04 & 0.02 & 0.00 & -0.01 & -0.05 & -0.01 & 0.05 & -0.04 & -0.09 & 1.00 & & & \\
\hline 19 & Market Uncertainty $\mathrm{t}_{\mathrm{t}-1}$ & 7.80 & 18.11 & 0.00 & 0.04 & 0.08 & -0.04 & 0.02 & -0.04 & 0.00 & 0.01 & 0.04 & -0.01 & 0.00 & 0.01 & 0.02 & -0.01 & 0.01 & 0.02 & 0.07 & -0.01 & 1.00 & & \\
\hline 20 & $\begin{array}{l}\text { Family Firms Regional } \\
\text { Presence } \mathrm{t}_{-1}\end{array}$ & 85.09 & 54.73 & -0.01 & 0.03 & 0.03 & 0.13 & -0.07 & 0.57 & -0.01 & -0.06 & 0.04 & 0.08 & 0.01 & 0.00 & 0.04 & 0.05 & -0.01 & 0.08 & -0.04 & 0.02 & -0.02 & 1.00 & \\
\hline 21 & Inverse Mills & 1.56 & 1.45 & 0.04 & 0.19 & 0.41 & -0.57 & 0.44 & 0.03 & -0.03 & 0.12 & 0.19 & 0.00 & -0.05 & -0.06 & 0.13 & 0.07 & 0.03 & 0.28 & 0.71 & -0.11 & 0.07 & -0.13 & 1.00 \\
\hline
\end{tabular}


Table 3

Estimated Parameters and Robust Standard Errors for Random-Intercept Logit Models for Introduction of Product Innovations

\begin{tabular}{|c|c|c|c|c|c|}
\hline Variable & Model 1 & Model 2 & Model 3 & Model 4 & Model 5 \\
\hline \multicolumn{6}{|l|}{ Fixed part } \\
\hline \multirow[t]{2}{*}{ Family Firm ${ }_{\mathrm{t}-1}$} & & $-0.27 *$ & $-0.91 *$ & $-0.48 * *$ & $-1.09 * *$ \\
\hline & & $(0.13)$ & $(0.38)$ & $(0.18)$ & $(0.40)$ \\
\hline \multirow[t]{2}{*}{ Ownership-based Exclusiveness $\mathrm{t}_{\mathrm{t}-1}$} & & $-0.57^{*}$ & $-1.16^{* *}$ & $-0.60^{*}$ & $-1.18^{* *}$ \\
\hline & & $(0.25)$ & $(0.44)$ & $(0.25)$ & $(0.45)$ \\
\hline \multirow[t]{2}{*}{ Region-based Exclusiveness ${ }_{\mathrm{t}-1}$} & & -0.02 & -0.02 & -0.42 & -0.43 \\
\hline & & $(0.45)$ & $(0.46)$ & $(0.55)$ & $(0.52)$ \\
\hline \multirow[t]{2}{*}{$\begin{array}{l}\text { Ownership-based Exclusiveness x Family } \\
\text { Firm }_{t-1}\end{array}$} & & & $1.31 *$ & & $1.27 *$ \\
\hline & & & $(0.64)$ & & $(0.65)$ \\
\hline \multirow[t]{2}{*}{ Region-based Exclusiveness x Family Firm ${ }_{t-1}$} & & & & $1.13 \dagger$ & $1.00 \dagger$ \\
\hline & & & & $(0.59)$ & $(0.58)$ \\
\hline \multirow[t]{2}{*}{ Number of Adopters ${ }_{t-1}$} & $0.02 * * *$ & $0.02 * * *$ & $0.02 * * *$ & $0.02 * * *$ & $0.02 * * *$ \\
\hline & $(0.00)$ & $(0.00)$ & $(0.00)$ & $(0.00)$ & $(0.00)$ \\
\hline \multirow[t]{2}{*}{ Adopters' Average Performance ${ }_{\mathrm{t}-1}$} & 0.23 & 0.19 & 0.04 & 0.18 & 0.03 \\
\hline & $(0.68)$ & $(0.67)$ & $(0.64)$ & $(0.68)$ & $(0.65)$ \\
\hline \multirow[t]{2}{*}{ Product Innovation $_{\mathrm{t}-1}$} & $2.35 * * *$ & $2.35 * * *$ & $2.36 * * *$ & $2.36 * * *$ & $2.36 * * *$ \\
\hline & $(0.15)$ & $(0.15)$ & $(0.15)$ & $(0.15)$ & $(0.15)$ \\
\hline \multirow[t]{2}{*}{ Social Performance Feedback $\mathrm{t}_{\mathrm{t}-1} \leq 0$} & $0.74 *$ & $0.77^{*}$ & $0.78^{*}$ & $0.78^{*}$ & $0.79 * *$ \\
\hline & $(0.32)$ & $(0.33)$ & $(0.33)$ & $(0.33)$ & $(0.30)$ \\
\hline \multirow[t]{2}{*}{ Social Performance Feedback $\mathrm{t}-1_{1}>0$} & $-0.34 \dagger$ & $-0.34 \dagger$ & $-0.35 \dagger$ & $-0.35 \dagger$ & $-0.35^{*}$ \\
\hline & $(0.18)$ & $(0.18)$ & $(0.18)$ & $(0.18)$ & $(0.18)$ \\
\hline \multirow[t]{2}{*}{ Slack Index ${ }_{\mathrm{t}-1}$} & -0.01 & -0.01 & -0.01 & -0.01 & -0.01 \\
\hline & $(0.03)$ & $(0.03)$ & $(0.03)$ & $(0.03)$ & $(0.02)$ \\
\hline \multirow[t]{2}{*}{ R\&D Intensity ${ }_{t-1}$} & $10.11 * * *$ & $10.13 * * *$ & $10.39 * * *$ & $10.17 * * *$ & $10.42 * * *$ \\
\hline & $(2.40)$ & $(2.40)$ & $(2.40)$ & $(2.38)$ & $(2.28)$ \\
\hline \multirow[t]{2}{*}{ Number of Patents ${ }_{t-1}$} & $-0.01 * * *$ & $-0.01 * *$ & $-0.01 * *$ & $-0.01 * *$ & $-0.01 * * *$ \\
\hline & $(0.00)$ & $(0.00)$ & $(0.00)$ & $(0.00)$ & $(0.00)$ \\
\hline \multirow[t]{2}{*}{ Product Diversification $_{\mathrm{t}-1}$} & $0.11^{*}$ & $0.11^{*}$ & $0.11^{*}$ & $0.11^{*}$ & $0.12 *$ \\
\hline & $(0.06)$ & $(0.05)$ & $(0.05)$ & $(0.05)$ & $(0.05)$ \\
\hline \multirow[t]{2}{*}{ Firm Age } & -0.00 & -0.00 & -0.00 & -0.00 & -0.00 \\
\hline & $(0.00)$ & $(0.00)$ & $(0.00)$ & $(0.00)$ & $(0.00)$ \\
\hline \multirow[t]{2}{*}{ Firm Size $_{\mathrm{t}-1}$} & $0.40 * * *$ & $0.40 * * *$ & $0.39 * * *$ & $0.39 * * *$ & $0.39 * * *$ \\
\hline & $(0.05)$ & $(0.05)$ & $(0.05)$ & $(0.05)$ & $(0.04)$ \\
\hline \multirow[t]{2}{*}{ Market Competition $_{\mathrm{t}-1}$} & $-0.00 * * *$ & $-0.00 * * *$ & $-0.00 * * *$ & $-0.00 * * *$ & $-0.00 * * *$ \\
\hline & $(0.00)$ & $(0.00)$ & $(0.00)$ & $(0.00)$ & $(0.00)$ \\
\hline \multirow[t]{2}{*}{ Market Uncertainty $\mathrm{t}-1_{1}$} & $0.00 * *$ & $0.00 * *$ & $0.00 * *$ & $0.00 * *$ & $0.00 * *$ \\
\hline & $(0.00)$ & $(0.00)$ & $(0.00)$ & $(0.00)$ & $(0.00)$ \\
\hline Family Firms Regional Presence $_{t-1}$ & $0.00 * * *$ & $0.00^{*}$ & $0.00^{*}$ & $0.00^{*}$ & $0.00 * *$ \\
\hline & $(0.00)$ & $(0.00)$ & $(0.00)$ & $(0.00)$ & $(0.00)$ \\
\hline Inverse Mills & $-0.10 \dagger$ & $-0.11 \dagger$ & $-0.11 \dagger$ & $-0.11 *$ & $-0.11 *$ \\
\hline & $(0.05)$ & $(0.06)$ & $(0.06)$ & $(0.06)$ & $(0.04)$ \\
\hline Constant & $-10.08 * * *$ & $-9.60 * * *$ & $-9.22 * * *$ & $-9.48 * * *$ & $-9.11 * * *$ \\
\hline & $(0.78)$ & $(0.83)$ & $(0.76)$ & $(0.80)$ & $(0.72)$ \\
\hline Random part & & & & & \\
\hline Firm & $1.10^{* * *}$ & $1.10 * * *$ & $1.10 * * *$ & $1.10 * * *$ & $1.10 * * *$ \\
\hline & $(0.09)$ & $(0.09)$ & $(0.10)$ & $(0.09)$ & $(0.10)$ \\
\hline Industry & $0.24 * *$ & $0.23 * *$ & $-0.19 \dagger$ & $0.22 * *$ & $-0.19 \dagger$ \\
\hline & $(0.09)$ & $(0.08)$ & $(0.10)$ & $(0.08)$ & $(0.10)$ \\
\hline df & 28 & 31 & 32 & 32 & 33 \\
\hline Log-likelihood & -3642.91 & -3639.32 & -3637.69 & -3637.18 & -3635.61 \\
\hline $\begin{array}{l}\text { Likelihood ratio } \chi^{2} \\
d f(\text { vs. Model \#) }\end{array}$ & & $\begin{array}{c}7.19^{*} \\
3 \text { (vs M1) }\end{array}$ & $\begin{array}{c}10.44^{*} \\
4 \text { (vs M1) }\end{array}$ & $\begin{array}{c}11.46^{*} \\
4 \text { (vs M1) }\end{array}$ & $\begin{array}{c}14.60 * * \\
5(\mathrm{vs} \mathrm{M} 1)\end{array}$ \\
\hline Wald Test for interactions $\chi^{2}(d f)$ & & & $3.82 *(1)$ & $3.66 \div(1)$ & $6.30 *(2)$ \\
\hline $\begin{array}{l}\text { Note: } \\
\mathrm{N}=12426 ; \text { Firm } \mathrm{n}=2338 \text {; Industry } \mathrm{n}=20 \\
\text { Huber-White robust standard errors in parent } \\
\dagger \mathrm{p}<.10 ; * \mathrm{p}<0.05 ; * * \mathrm{p}<0.01 ; * * * \mathrm{p}<0.0\end{array}$ & models & rol for yes & & & \\
\hline
\end{tabular}


Table 4

Results of GEE Regression Analysis for Number of New Products

\begin{tabular}{|c|c|c|c|}
\hline Variable & Model 1 & Model 2 & Model 3 \\
\hline \multirow[t]{2}{*}{ Propensity to Conform ${ }_{\mathrm{t}-1}$} & & $2.28 * * *$ & $1.78 * * *$ \\
\hline & & $(0.48)$ & $(0.46)$ \\
\hline \multirow[t]{2}{*}{ Family Firm $_{\mathrm{t}-1}$} & & -0.19 & $-0.78^{*}$ \\
\hline & & $(0.23)$ & $(0.31)$ \\
\hline \multirow[t]{2}{*}{ Propensity to Conform $x$ Family Firm ${ }_{t-1}$} & & & $1.68^{*}$ \\
\hline & & & $(0.68)$ \\
\hline \multirow[t]{2}{*}{ Number of Adopters ${ }_{t-1}$} & -0.01 & $-0.01 *$ & $-0.02 * *$ \\
\hline & $(0.01)$ & $(0.01)$ & $(0.01)$ \\
\hline \multirow[t]{2}{*}{ Adopters' Average Performance $_{\mathrm{t}-1}$} & -1.31 & -1.14 & -1.25 \\
\hline & $(1.30)$ & $(1.28)$ & $(1.34)$ \\
\hline \multirow[t]{2}{*}{ Product Innovation $_{\mathrm{t}-1}$} & $2.19 * * *$ & $2.53 * * *$ & $2.44 * * *$ \\
\hline & $(0.21)$ & $(0.25)$ & $(0.25)$ \\
\hline \multirow[t]{2}{*}{ Social Performance Feedback $\mathrm{t}_{\mathrm{t}-1} \leq 0$} & -0.04 & -0.13 & -0.11 \\
\hline & $(0.37)$ & $(0.46)$ & $(0.46)$ \\
\hline \multirow{2}{*}{ Social Performance Feedback $\mathrm{t}_{\mathrm{t}-1}>0$} & $-0.52 *$ & $-0.51 *$ & $-0.48 \dagger$ \\
\hline & $(0.25)$ & $(0.26)$ & $(0.26)$ \\
\hline \multirow[t]{2}{*}{ Slack Index ${ }_{\mathrm{t}-1}$} & 0.02 & 0.01 & 0.01 \\
\hline & $(0.03)$ & $(0.03)$ & $(0.03)$ \\
\hline \multirow[t]{2}{*}{ R\&D Intensity $t-1$} & $1.90 \dagger$ & 1.10 & 0.99 \\
\hline & $(1.14)$ & $(1.27)$ & $(1.30)$ \\
\hline \multirow[t]{2}{*}{ Number of Patents ${ }_{\mathrm{t}-1}$} & -0.00 & -0.00 & -0.00 \\
\hline & $(0.00)$ & $(0.01)$ & $(0.01)$ \\
\hline \multirow[t]{2}{*}{ Product Diversification $_{\mathrm{t}-1}$} & -0.11 & $-0.33 * *$ & $-0.32 * *$ \\
\hline & $(0.09)$ & $(0.12)$ & $(0.12)$ \\
\hline \multirow[t]{2}{*}{ Firm Age } & 0.00 & 0.00 & 0.00 \\
\hline & $(0.01)$ & $(0.00)$ & $(0.00)$ \\
\hline \multirow[t]{2}{*}{ Firm Size $_{t-1}$} & 0.10 & -0.08 & -0.09 \\
\hline & $(0.07)$ & $(0.09)$ & $(0.09)$ \\
\hline \multirow[t]{2}{*}{ Market Competition $_{\mathrm{t}-1}$} & 0.00 & $0.01 *$ & $0.01 *$ \\
\hline & $(0.00)$ & $(0.00)$ & $(0.00)$ \\
\hline \multirow[t]{2}{*}{ Market Uncertainty $\mathrm{t}_{\mathrm{t}-1}$} & -0.00 & -0.00 & -0.00 \\
\hline & $(0.00)$ & $(0.00)$ & $(0.00)$ \\
\hline \multirow[t]{2}{*}{ Family Firms Regional Presence ${ }_{t-1}$} & -0.00 & -0.00 & -0.00 \\
\hline & $(0.00)$ & $(0.00)$ & $(0.00)$ \\
\hline \multirow[t]{2}{*}{ Inverse Mills } & -0.12 & -0.11 & -0.09 \\
\hline & $(0.12)$ & $(0.14)$ & $(0.14)$ \\
\hline \multirow[t]{2}{*}{ Constant } & -1.90 & 0.63 & 1.04 \\
\hline & $(1.22)$ & $(1.43)$ & $(1.38)$ \\
\hline $\mathrm{df}$ & 24 & 25 & 27 \\
\hline Wald $\chi^{2}$ & $633.64 * * *$ & $681.20 * * *$ & $661.16^{* * *}$ \\
\hline QIC & 76388.87 & 57310.27 & 57074.07 \\
\hline Wald Test for interactions $\chi^{2}$ & & & $6.21 * *$ \\
\hline $\begin{array}{l}\text { Note: } \\
\mathrm{N}=9872 ; \text { Firm } \mathrm{n}=2056 \\
\text { Huber-White robust standard errors in } \mathrm{p} \\
\dagger \mathrm{p}<.10 ; * \mathrm{p}<0.05 ; * * \mathrm{p}<0.01 ; * * * \mathrm{p}\end{array}$ & control for & & \\
\hline
\end{tabular}




\section{Figure 1}

Four Rationales for Conformity

Degree of distinctiveness of the focal firm's social category

Low

High

Degree of

exclusiveness of

a behavior to the

focal firm's

social category

\begin{tabular}{|c|c|c|}
\hline & Low & High \\
\hline High & Conformity-in-conformity & $\begin{array}{l}\text { Conformity-in-distinctiveness } \\
-\quad \text { Necessary to avoid social } \\
\text { losses }\end{array}$ \\
\hline Low & $\begin{array}{l}\text { Distinctiveness-in-conformity } \\
-\quad \begin{array}{l}\text { Necessary to reap social } \\
\text { gains }\end{array}\end{array}$ & Distinctiveness-in-distinctiveness \\
\hline
\end{tabular}

\section{Figure 2}

Predicted Marginal Probability as a Function of Ownership-Based Exclusiveness of New Product Introduction for Family versus Nonfamily Firms

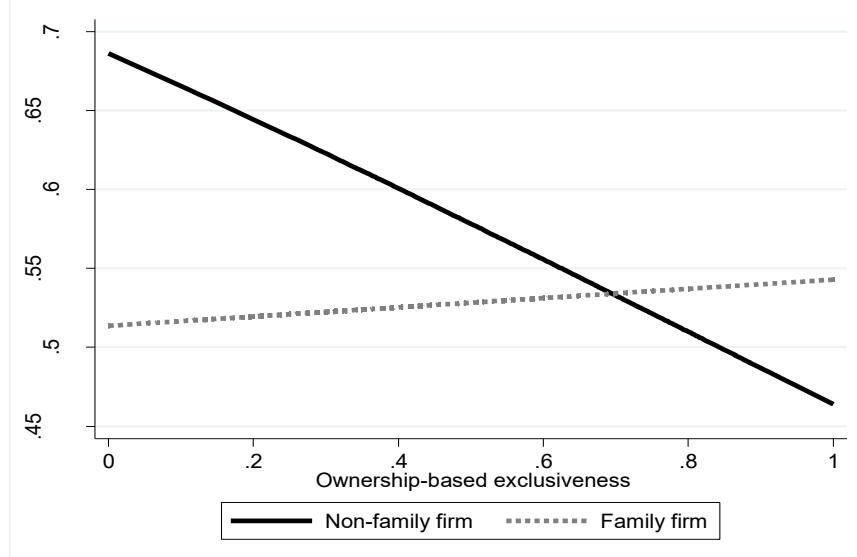

\section{Figure 3}

Predicted Marginal Probability as a Function of Region-Based Exclusiveness of New Product Introduction for Family versus Nonfamily Firms

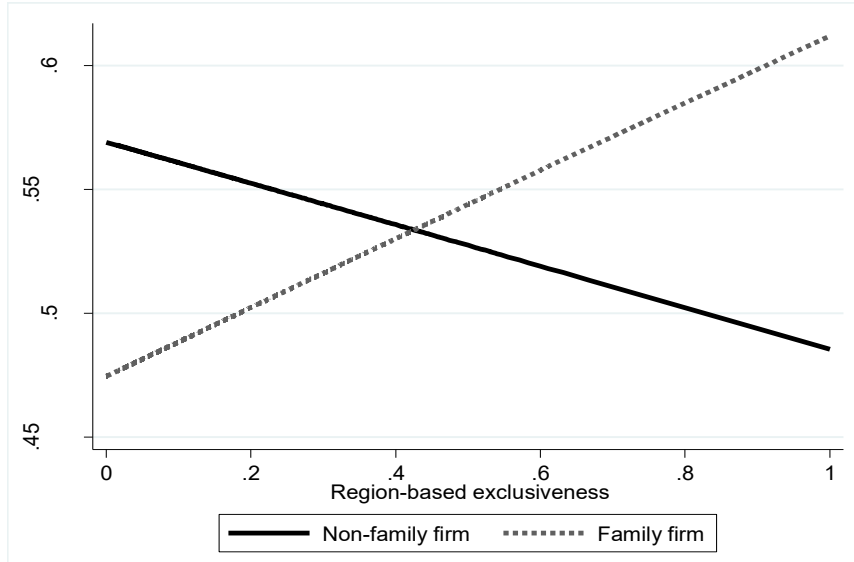

